\title{
The "Symbolic-identitarian" Policies: The Case of Naples, Italy
}

\author{
Marco Cilento \\ marco.cilento@uniroma1.it
}

\section{Doi:10.5901/ajis.2015.v4n3s1p45}

\begin{abstract}
Italian political scene and policy-making process, at local government level, have profoundly changed over the past 20 years. In the context of the Italian reforms of the 1990s, the most glary manifestations of the so-called "direttismo" were: the crisis of political parties; the personalization of politics; the fiscal crisis of the state; the need for activation of the processes of accountability. All these factors have been reflected in the role of the mayor, who because of regulatory constraints and policy needs, indulges in the use of symbolic policies. This paper attempts a more systematic definition of symbolic policies. In particular, the hypothesis which has to be developed puts emphasis on the socio-political-professional background of the mayor as a variable that can explain the level of success of symbolic policies. A first test is attempted in relation to the case study of Naples.
\end{abstract}

Keywords: local policies, mayor, personalization, symbolic policies, leadership, Naples.

For several decades, Italian politics has already been affected by the wind of change, since the second half of the 70s of the last century (Donolo 1977). It has been insistently discussed about "Italian transition", almost such as a permanent condition (Pasquino 2000; Tranfaglia 2003; Ceccanti, Vassallo 2004). The only political-administrative level where the transition has effectively accomplished is the local one: especially in the communal context, even from a regulatory point of view, some changes occur in roles, functions, and relations between the political and institutional actors and, consequently, the degree of accountability. To the demo-elected mayor there were attributed all levels of responsibility in local politics, in a dynamic of enhanced "direttismo" that hardly manages to be balanced with the needs and administrative constraints (Vandelli 1997; Vandelli 2014; Caciagli, Di Virgilio 2005). The issue is part of the most comprehensive debate on urban reform and local government, which has always been particularly fervent in the United States of America (Lowi 1964; Dahl 1961; Hunter 1953; Welch, Bledsoe 1988; Svara \& Associates 1994).

The recent experience of local government in Italy has undoubtedly highlighted the new dynamics of policy making which should be viewed in the imbalance between research and consolidation of consent on one hand, and the ordinary administrative management on the other hand (Baccetti 1999; Cilento 2000; Catanzaro et al. 2002; Morello 2007; Canzano 2012). Agenda-setting; composition of policy-making typologies; articulation of the policy cycle: these are the slopes of policies that have seen the most significant changes at the local level in recent decades. Equally significant were the innovations of politics introduced in the local government in Italy since the 90s of the last century, or that arose spontaneously in the local socio-political context: party deconstruction; new role of political and institutional actors; new rules and standards; innovative models of decision-making. In the analysis of the abovementioned processes, the two levels (politics and policy) intersect and overlap in an increasingly controversial causative dynamic (Easton 1953; Lowi 1972; Cotta 1989). It has been developed a little the role of leadership as a variable of agency in the change of local policies (Capano 2009). Local policies are increasingly characterized by the prevalence of symbolic elements, with different levels of effectiveness. Can the effectiveness of so-called "symbolic policies" (Edelman 1976; Cilento 2000) be traced back to the different profile of elites who are ranked at the top of the municipalities?

The paper aims to articulate, although partially, the abovementioned hypothesis. The first part analyzes the local policy change, in particular the type of symbolic policies increasingly common - and used - by the demo-elected mayors as a means of consolidation of consent. The hypothesis that, parameterized all variables of politics, the effectiveness and success of the symbolic and identity policy of the new mayors may be related to the leadership profile of the latter, and the different potential of their being political and / or policy entrepreneurs, is just outlined in reference to the case study of the charge of the Neapolitan Mayors Bassolino (1993-1997) and De Magistris (2011-): in the same socio-political context, at a distance of about twenty years, the major / minor success policy initiatives of two mayors in comparison can be traced back to the profile of the elite that they embody. This is just a mentioned hypothesis that requires other analyses and verifications to find any possible validation. 


\section{The Policy Making of "New" Mayors: The Symbolic Policies}

With the reforms introduced since the 90s, the local policy making has seen many changes to develop and take shape on various levels: the agenda-setting; the composition for functional areas of policy; the articulation of the policy cycle; the impact and feedback. Concerning the agenda-setting phase, compared to the past it has clearly failed the function of aggregation and structuring of political demand, once exerted by the parties (Calise 1992; Cotta, Isernia 1996; Ignazi 2002). The increasing volatility and deconstruction of the parties has determined their inability - or surrender - to perform the role of "flywheel" and the transmission belt between the institutions and the society (Mény, Surel 2001; Mair 1992). Locally, the pressing process of personalization and unrestrainable "direttismo" (Venturino 1995; Melchionda 2005) has exasperated, both in political and normative terms, the exposure of the mayor in terms of responsiveness and accountability. The absolute priority of strengthening the consensus induces the mayor to bypass all levels of mediation and to act as sole interpreter of the changing trend of the public opinion, through the massive use of new media, in the first place of the survey as well as of social media (Marletti 2010; De Rosa 2013; Bentivegna 2014). The polls replace in all respects the "intelligent terminals" represented by the political parties "the media replace the parties both as mechanisms for the selection of the political class and as tools to mobilize the public opinion or the definition of the political program" (Mény, Surel 2001, 111). The phenomenon of "mediatization" of politics in contemporary era should be identified on the basis of two different perspectives: the impact on electoral competitions, certainly the most studied side in the political science literature and sociology; the conditioning of government processes at all levels. The boundaries between campaigning and moments in which it governs, however, have gradually dissolved: "the problem of maintaining or buying popularity through strategies of image is already present also in non-electoral periods, in the constant effort that politicians and consultants who assist them make to try to obtain the approval, the popularity among the citizens and the consent around their policies "(Grieco 1997).

For what concerns the types of policies increasingly recurring locally after the reform, it should be provided that the decline of the politics in collective terms has ousted completely even the persuasive-pedagogical function of parties and groups. If in the past, on the particularly negative and punitive effects of some public policies, were established the guarantees of parties and groups, which enjoyed a high reputation among the public, in the post-reform era, the "material" policies (redistributive and distributive) and "at no cost" (redistributive) (Lowi 1972; Calise 1988) are superseded - in number and effectiveness - from the "public opinion" policies (Castells 2009; Pasotti 2010). The "mother" of all the reforms at the local level should have been the reorganization of the Municipal administrative machinery, to adapt to the new governance mechanisms introduced by Law 81/93. Such a reform, to use the classification scheme of Lowi, cuts across most areas, being able to be identified as a redistributive, regulatory and constituent policy. The categorical imperative of popular consensus to be achieved on the basis of the beneficial effects for the community of municipal politics, led the "new" mayors to give up the intentions of reform and rationalization of the administrative municipal, and to avoid, insofar as possible, those policies to higher incidence and administrative characterization. This belief is not determined immediately in the minds of mayors but matured at different stages depending on the different experiences of government to which the new leadership of local governments had to cope, especially in major Italian cities. Nevertheless, there were initial attempts in the sign of the reorganization of the bureaucratic machine. For example, it is the singular emphasis with which Antonio Bassolino, Mayor of Naples from 1993 to 2000, in February 1994 told the first results achieved by the disciplinary committee, established after four years of empty, examining more than a thousand cases of absenteeism to the City of Naples: they were 42 dismissed, 150 suspended and 700 employees to which was applied the reduction in salary; furthermore it was decided to mobility for 1729 employees redundant (Brown 1996). Valentino Castellani in Turin, mayor from 1993 to 2001, initially pointed to a reordering of the vertices of the municipal bureaucracy, reducing its seats from 87 to 22, but then realized that more profound impact in that area would be extremely long and expensive (Vandelli 1997).

More generally, it must be said that the dynamics of consensus politics have changed radically: they do not refer anymore to ideological factors neither to constraints of party affiliation or class, having lost at the same time its traditional character of stability (Lakoff 2008). The joint effect of the personalization of the political leadership and the introduction of new electronic media has determined a strong link between the level of popularity and consent (Calise 2010). The extreme volatility and immediacy of new mechanisms of consent led to give importance primarily to emotional and symbolic factors in the mode of entry into a political leader or in a issue with this proposal: more often, the manifest intention of solving a particular issue can get feedback in terms of popularity and consensus, that is greater than the direct effect of the policy itself. The decision process is charged, therefore, with symbolic characterization. It has established, gradually, a communication strategy consisting in the attempt from the political leader to impose his/her own 
image, security and optimism, as well as his/her point of view before the citizens, through a scientific use of media and techniques of political marketing. It is, however, a complete emptying of the contents of politics, its progressive spectacle, where an emotional attitude - sympathy, for example - the symbols and the images are much more than the actual results that a political leader obtains. It has emerged, increasingly, a policy of appearances and inauthenticity (Fabbrini 1990). The situation developing in the local arena, after the reforms of the $90 \mathrm{~s}$, in greater measure highlights the preconditions and effects - of personalized policy: direct election of the mayor, a tyrannical concentration in the sense of power and its authority. It has established a direct relationship between the mayor and all the citizens, no longer mediated by the parties. In addition, the close proximity between the mayor and his community of reference has helped to characterize in terms of confidence-responsiveness-control, the above mentioned relationship, giving particular importance to the symbolic aspects and charismatic leadership of the mayor.

In the new political conditions locally determined, the mayor is increasingly aimed at the consolidation of his/her arena of political-electoral consent than attentive to the constraints constituted by the organization of which he/she is the head; accordingly, especially at the beginning of its mandate, the mayor tends to enter the agenda potentially universalistic institutional issues, above the lines of partisanship and traditional cleavages (Pasotti 2010), accepted as such by the media and recognized as a priority by the public. It is decisive, in this context, also the time variable, which will deepen later: the mayor should primarily look after consolidating their consent in view of confirmation to the guide of the town, within the span of the five-year term provided. Therefore there will be preferably activated policy interventions with immediate political impact and rapid and effective implementation. The immediate politically unprofitable policies with high costs and long-term results - are postponed compared to interventions at immediate effect and politically profitable for the administration in charge. The policy making which have been promoting by the "new" mayors prefigures a new category of public policies, which can be defined as symbolic (Cilento 2000). In the case of local governments at direct popular investiture, the symbolic policies do not seem to designate a class of its own policy, but are symptomatic of a new mode of politics: they are transversal, going to connote regulatory areas traditionally belonging to other categories of policy. The first who introduced the concept of symbolic policy was Edelman (1976): he referred to public activities whose essence lies not in acting, but in saying, in knowing and believing who acts or who is concerned to intervene. The symbolic policy "indicates a positive fact, an intention or a prescription of a particular type. The important thing is that the decision has been taken. If any application does not intervene, if there is no implementation, this is due to the fact that the stake is - for the public authority concerned - in obtaining a declaratory effect towards the community or to specific recipients "(Mény, Thoenig 1991, 209). Initially the Edelman's thesis was assimilated to the classic strand of the political deception and of the exploitation of the emotions of the masses and their suggestibility in front of myths, for instrumental purposes and interest. Conversely, Edelman has often pointed out that "although the symbolic policies are misleading, however they are not a deliberate deception. In fact, the most effective political symbolisms are propagated by people who believe in themselves. The point is that the effective governments' acts and statements are rarely simple in their consequences and in their meaning "(Edelman 1976, 479). The actuality of Edelman comes from the fact that the aggregation of interests and policy-making related to the formation of public policies follow pattern of development rarefied and sophisticated; and they are averaged and concerted following logical mostly incomprehensible outside the narrow circle of insiders. The emergence of this logic of symbolic mediation, as emphasized Marletti (1986), can be explained only in part with the classical hypothesis of political deception, i.e. the intention on the part of governments to manipulate the governed. The symbolic policies have a dual function: to the broad public they are presented as hortatory speech, that dramatizes some issue bringing public attention on possible alternative solution, allowing the political process of role taking, recruitment of public responsibility, in order to reassure the public that in the face of a crisis or an emergency it is working on a political solution, it is taking steps effectively (Marletti 1986). Therefore the functions of dramatization and reassurance move in symbolic form outside determining the maximum level of consent.

The consolidated practice locally hitherto in two decades of experimentation of the reform, highlighted new features that enrich the three already identified at the base of the definition of symbolic policies. The first three defining characteristics of symbolic policies were thus shown (Cilento 2000):

1. Politically not-divisive, ecumenical, policies that do not involve transfers of material resources (both economic and in kind) for the benefit of a particular field of citizenship or to the detriment of others and that, therefore, involve a low level of public conflict ;

2. low administrative policies, both in the sense that have relatively little impact on the operation of the bureaucratic machine, and in reference to the fact that imply a more limited amount of production and administrative activities;

3. They imply high exposure and visibility of the mayor and council, with strong media coverages. 
The other two aspects that have been consolidated as characterizing the symbolic policies in their declination in the local area, have a bearing, in the first case, with the "brand politics" (Pasotti 2010): these policies, particularly focused on the enhancement of the historical and cultural territories, encourage feelings of civic culture and belonging, through the identification of citizenship in the person of the mayor and his/her policies initiatives. Such policies could more appropriately be defined "identitarian": through a deep action of persuasion, the mayors get from citizenship strong legitimacy that can create the preconditions to activate, at a later time, policy interventions more unpopular and controversial (transport, urban development). The second innovative aspect of these symbolic-identitarian policies, closely linked to the previous one, is the time: they are short-term policies, the effects of which do not have a long life. This leads us to consider the time factor, deepened by Capano (2009a). The different elements that make up the temporal dimension of policies (timing, time span, temporality, intensity, duration, sequence), for our analysis to be relevant is certainly the timing. "The concept of timing also refers to the temporal contingency that may be favorable or unfavorable to certain policy choices. In this sense, for example, the diversity of the timing between public policy and the political dynamic (think of the logic and the sequence of the political and electoral cycles) can be a significant constraint for reforms ('it is not the right time to groped to do certain things')" (Capano 2009a, 16). According to the perspective and strategy of the "new" mayors, the timing of local policies is an independent variable: the choice of actions to be initiated is strongly influenced by the need, politically and electorally, to consolidate, within the span of five years of mandate, their level of consent by initiatives taken quickly and effectively. So the priority should be given to interventions that strengthen the bond of trust between the mayor and the citizens and enable dynamic participation/civic identification functional to a more general revival of the municipal context (Fung 2004). Such policies require constant attention of the media to keep alive the mobilization of consciences and the public but, if not accompanied by initiatives that put in place material resource, tend to fade over time the positive effects of their action.

From the empirical analysis of the types of policies locally adopted, and their level of effectiveness, there are three groupings: the more substantial improvements were noted in the urban environment and public green, relations with citizens, organization of the municipal machine, school and culture; follow health policies, social policies, home, transport, roads; finally, urban planning and economic development. The first set of policies are characterized by a high visibility, strong symbolic component, relatively inexpensive interventions in terms of economic and less confrontational in terms of relationship with the groups of interest: they are also called " easier policies." The other categories of policy are more expensive in terms of financial and require an effort of relations with institutional levels higher and partly with users and with the private sector, in particular the interest groups whose choices are crucial for achieving significant results (Trigilia 2002). The mayors with strong leadership, both in terms of personal qualities and political experience gained previously, have carried out a more innovation policies. The climate of greater confidence and growth of positive expectations proved to be an important ingredient, but not sufficient, to take steps forward in more complex and difficult policies. The depoliticization of the traditional cleavages is linked to the role of culture in politics: according to a negative view, culture would produce consensus, marginalization of dissent, activation of soft power through pride; a positive reading identifies culture with the promotion of the empowerment of citizens, equal participation, civic-mindedness (Pasotti 2010). Generally, in analyzing the political choices and voting behavior, emotions and rationality are opposed (Calise 2010). The new local symbolic-identitarian policies combine, however, the two levels: in order to initiate reforms in the city plagued by corruption, apathy and lack of development, the mayors offer a radically opposite perspective to the usual one in which citizens must identify themselves. While the bonds in the politics of patronage are based on expectations of exchange, public policy relies on the activation of the emotions (Pasotti 2010; Kavaratzis 2004). It appears to be more important the process of identification and self-esteem that the considerations of income, more relevant analyzes of cognitive psychology than those of the economy. And it is strong, in such cases, the representation for identity (Pitkin 1967), the voter must understand the candidate as "one of us".

To conclude the analysis of changes in local policy making, the last two aspects - the articulation of the policy cycle, the impact and feedback - are strictly consequential to what has been described above. About the articulation of the policy cycle, the symbolic-identitarian factor - so strong at local level - determined that the phases of the relevant policy are certainly to be found in the formulation and agenda-setting by the decision maker, moved by the need - and constraints - to consolidate the consensus; in these conditions, given the low impact, in administrative terms, related to the "new" mayors' policies, the implementation phase plays a marginal role. Regarding the impact/feedback phase, the dominant emotional-cognitive matrix minimizes the material impact of the policy in question and implies a positive feedback in terms of consent in the short term, then requiring the use of intervention strategies less persuasive and more substantial, in order to maintain a high level of consensus.

Anxiety and the urgency of the consolidation of the consensus that has often led mayors to resort to the "short-cut" 
symbolic-identitarian policies is not always proved to be an effective way. The evidence of such political paths varies depending on the experiences and contexts in which they developed. In the last part of the paper we will try to point out some hypotheses to explain the differences in impact determined by the policies in question; reference will be made, in the conclusions, to the hypothesis that to affect the process - and effect - of the symbolic-identitarian policies can be the profile, the role and the array of local leadership. As an example, in the next section will be synthetically reconstructed some policies put in place by the two mayors of Naples Bassolino and De Magistris, to better articulate the range of variability of the local symbolic-identitarian policies.

\section{The Symbolic-identitarian Policies in Naples: Bassolino and De Magistris in Comparison}

The administrative experience of Antonio Bassolino (1993-2000) and Luigi De Magistris (2011-) at the head of the City of Naples were characterized, although after almost twenty years, for some common traits and other totally dissimilar. The mandates of the two mayors were part of a policy framework, national and local, very special and, in several aspects, similar. Bassolino settled at Palazzo S. Giacomo in 1993, during the height of the storm of Tangentopoli and the wave of anti-politics: the former mayor, the Socialist Nello Polese, had been placed in handcuffs just in the headquarters of the municipality, with allegations of malfeasance and receiving stolen goods. De Magistris was elected, in 2011, after a decade in charge as the mayor of Rosa Russo lervolino that even in this case, had ended with notices of investigation and arrest against some assessors for criminal conspiracy. Both administrative experiences were part of a context of profound party deconstruction and strong anti-politics wave: it should be emphasized the fact that De Magistris was elected as representative of a civic movement called "orange", which was connoted especially for being in opposition and in rejection of traditional politics. It comes, for both experiences, to a political laboratory, also considered as the specific nature of the socio-political-cultural metropolis of Naples, a lot of literature has been produced regarding this (Brown 1996; Geremicca 1997; Allum 1997; Barbagallo 1997; Cappelli 2003; Amato 2012; Mazziotti 2012; Tuccillo 2014). It was also attempted a parallel between the two elections, 1993 and 2011 (Amoretti, Musella 2011).

"The part that unites both experiences, by far the most significant differences, would be in fact the strong skepticism and disaffection of traditional politics. And, above all, a form of expression and exercise of leadership which in leveraging strategies and communication resources would activate circuits of mobilization and creation of "neoplebiscitarian" consensus. The cross-appeals and the almost messianic expectations of which are charged newlyelected mayors would be nothing but the coherent manifestation of correspondent adopted model of (anti) politics culture. Not by chance, in many interviews, there are the same Bassolino and de Magistris who have to defend themselves from the accusation of populism" (Amoretti, Musella 2011, 3).

At this point, we can briefly describe some of the policies that have characterized the two municipal administrations and that are still in the imagination of the citizen of Naples. The goal is to identify differences in approach and policy management in the subject that could, in theory, justify the different outcomes in terms of consensus and effectiveness.

Regarding the Bassolino administration, we must quote Aurelio Musi (2004, 20): "The first analysts reach their target when, for the first phase of Bassolino's mandate, underline that not just the politics of major projects, as the small steps, the "virtuous minimalism", a new collective identity for the city constitute the figure of the new Neapolitan administration". The closure to traffic of Piazza Plebiscito in Naples, wanted by Bassolino, is the most effective confirmation of what has been reported, as Bassolino told himself in an interview to Corriere del Mezzogiorno (15 May 2014): at the conclusion of G7 that was held in Naples in July 1994, it was precisely the then-Mayor of Naples, at night, who resumed the barriers that had fenced the area of the institutional summit, having decided the full closure to traffic of the square. The next day he informed the Municipal Junta of his decision, but the idea had been already long taken, in agreement with the Prefect and the Superintendent for artistic and historical heritage. At the base of this initiative there was the idea that the square, symbol of the city, would be returned to citizens, became the agora enjoyed by all Neapolitans, hosting initiatives of great collective attraction. The reconquered public space opposed the massacre represented by private vehicles, which until then had invaded the area of the square. It is clear the identitarian connotation behind this policy: the Neapolitan citizen who regains the possession of an area particularly full of cultural and historical value is reinforced in his civic sense of belonging to the local community. All this came through a quick, short administrative process (Mayoral Decree and Junta Resolution), with a very low impact on the municipal administrative resources but with a high media visibility: still the called "Neapolitan Renaissance" started by Bassolino during his first mayoral term (Geremicca 1997) has as its own symbolic image the "sitting room" square of the city full of Neapolitans who are walking. And this image has been conveyed, also thanks to the coincidence of the G7, somewhat in all latitudes of the planet. Although initially the total closure of the square had been challenged by traders of neighboring 
streets, worried about the negative relapse that this would have had on their business, the success in terms of tourism and media that the "new" square has determined ended up by putting all in agreement. Another particularly innovative public policy that was put in place in 1995 by Bassolino, then imitated by other mayors of Italian cities, was the issue of City Ordinary Vouchers (BOC) on the US financial market at Wall Street, in the amount of 300 billion lire, an operation aimed at the purchase of 425 new buses. The initiative was agreed with the then Assessor for Finance Roberto Barbieri and was a great success. The determination of the rating, ie the level of reliability municipal entity, was entrusted to Moody's and Standard \& Poor's; the US investment bank Merrill Lynch was commissioned to place the Neapolitan BOC on the international market. The operation was a huge success: the mayor and his administration were able to take advantage of the positive wave, internationally, created following the G7 in July 1994, to enable a fair process for all citizens, that is, the renewal of the means of local public transport. The Administration of Naples was able to take advantage of the financial difficulties besetting the common result of previous management policies, and took advantage of the positive image that in the meantime the city had gained in the international media arena. Again the administrative impact turned out really minimal, both in financial terms - the resources came from private overseas - and in terms of human resources. The creative originality of the initiative aroused the envy of the opposition in the City Council, to the point that at the instigation of Senator of Forza Italia Emiddio Novi, the public prosecutor of Naples began an investigation in 1998, against Bassolino and 11 of his former Assessors for abuse of office. In 2000 there was the acquittal with full formula of Bassolino and his assessors with the "not to prosecute because the crime does not exist." The prosecutor decided not to appeal: the policy in question was a success both politically and legally. The measure on the BOC is the most obvious example of a policy that, taking advantage and putting its assumptions about the intangible dynamics regained positive image of Naples in the world, high visibility of the administration in office - determines consequences and effects to high material and financial funds for the purchase of new buses.

Moving on to examine the most significant policy initiatives implemented by the Administration of De Magistris, still in office, it should be emphasized that in about a year after the elections of May 2011, the coveted "orange revolution" seemed to have all but vanished. The fiduciary relationship between the mayor and citizenship is cracked: De Magistris has not proved capable of imparting the revolutionary breakthrough that allowed him to win the election hands down; after a few months, it was found entangled in the "swamps" of trading party and blackmail of groups and social sectors - typical situations of the old politics. The innovative and anti-political nature of his election has quickly faded making his image and his profile leaders increasingly homologous to those of traditional politicians. His inability to follow a linear political strategy, and keeping promises to the electorate that had so many hopes on, it has considerably weakened at the political level: after three years from the election, he has lost most of the majority in the city council, which is based on his vote and that of the President of the City Council; with the exception of the Deputy Mayor and the Assessor for Education, in two years all the members of the junta have resigned or have been "dismissed" by the mayor. His current junta is composed primarily of representatives of parties, having lost its initial technical and innovative aspect. Moving on to examine two policies of the De Magistris' junta, the first reference is to the organization of the preliminaries of the America's Cup in Naples from 11 to 15 April 2012. Even De Magistris wanted to focus on the major international events to boost the image of Naples in the world, overshadowed by the garbage crisis that for years had tarnished reputation. The procedures followed to fund the initiative were the traditional ones: the investment was 12.2 million euro, of which 7.2 from European funds and the remaining between the Region, Province and Municipality. From an analysis of the economic impact of the event, presented about a year later by the University Parthenope, resulted triumphant data: it estimated 36 million euro of economic return - 16.2 of direct effect and 19.8 of indirect effect. Popular participation in the event was undoubtedly, significant: between 530 thousand and 775 hundred spectators. All of which helped to revive the brand of Naples worldwide. But soon after the problems came to the surface: first the organization of the event did not lead to the implementation of infrastructure and maintenance of permanent benefits to citizens; the only consequence of the event was the decision to close to traffic permanently the seafront, arousing the protests of the sellers in the area, primarily the hoteliers, who would have preferred the closure only on weekends and public holidays. Second, the significant funding behind the initiative put the De Magistris' administration under the lens of the judiciary, with the subsequent investigation of the June 2013 that, on several occasions, involving the leaders of the three public institutions bells, including De Magistris and the mayor's brother, Claudio, consultant for Great Events of the City of Naples, the president of the Industrial Union Paolo Graziano for the entry of Confindustria Naples as private partner of Acn (America's Cup Naples), the company created for the purpose of the event; President of the Chamber of Commerce, Maurizio Maddaloni. The investigation speculated the crimes of bid rigging, abuse of office and fraud. The policy in question, although it has got a strong media impact, came across in the "quicksand" of public contracts and concessions: that initiative was based on processes of outsourcing to private and it has triggered judicial levers, casting shadows on what 
today is recognized as the most successful initiative of the De Magistris junta. The other example of De Magistris'policy that we also considered falls in the category of major events: the organization of the Forum of Cultures, a trademark of the city of Barcelona entrusted, for 2013, the former member of the Bassolino's Junta Nicola Oddati. It should have been a great opportunity for bringing Naples to the glories of the G7 in 1994, a sort of Olympics of culture. One woud expect a rain of state funding, up to 150 million euro, to carry out also infrastructure works. However Nicola Oddati, in order to prepare the event, began to travel over the world, spending much and reporting little. Meanwhile, the government declassed the Forum of Cultures from national demonstration to regional one, gradually cutting the funds. De Magistris, after he took office, wanted to mark the difference from the previous phase: he first appointed Roberto Vecchioni the President of the Forum, that soon resigned; the same fate interested Ambassador Francesco Caruso; finally Sergio Marotta, university professor, grandson of Gerardo, soul of the Italian Institute for Philosophical Studies. Also Peppe Barra, an icon of Neapolitan music, left the Scientific Committee: he complained of a total vacuum of projects, employees were missing, the case was short of money. In the mid-2013, the organizers were forced to move the event from spring to autumn 2014: a real flop for an event included in the calendar as far back as 2008. Caldoro, President of the Region, and De Magistris decided to take to the "strong manners" appointing a commissioner at the head of the Forum and entrusting full powers to the accountant Alessandro Puca but the latter, after a few weeks, resigned. In May 2014 it was the turn of the last Commissioner, Daniel Pitteri, one who organizes cultural events, has been appointed Commissioner: it's up to him to spend 16 million euro allocated for the event, 11 million euro for Naples and 5 million euro for the rest of the region, but the real budget is 2 million euro. The result was that the Catalans were so irritated by how the Forum of Cultures' brand has been abused that they decided to seek damages. The story of the Forum of Cultures is emblematic, unlike the previous policy, of a wasted opportunity: the negative feedback that the image of the city of Naples has suffered from this experience should certainly be charged to scary organizational limits shown, in the first place, by the De Magistris Administration. The claim to be able to organize an event of such international scope has resulted in a series of disastrous decisions as well as the result of apparent lack of planning and strategic capacity. Not having been able to activate the appropriate synergies, institutional and private sources, in order to attract adequate funding, once again put out a sign of sloppy management of public affairs. The policy on the Forum of Cultures is probably one of the lowest points touched so far by the De Magistris Administration.

As it is clear from the summary of the policies' framework above reported, charisma and communication skills, by themselves, are not sufficient for mayors to administer properly the local authority. "Fundamental to this effect are revealed more specifically political and social skills, especially the experience gained in activities of a political nature, valuable in dealing with subjects that affect decision making. The "new mayors" that can be perceived as the most innovative are actually "old politicians" freed from the constraints of the previous institutional model, but with sufficient experience in dealing with bureaucracies, local councils, the majority parties and opposition, organizations of interest "(Trigilia 2002, 586). How to translate everything in local policies? In the Conclusions we will try to focus on this issue and to identify the leadership model best suited to strengthening the effectiveness of the policy making and consolidation of popular support for the mayor.

\section{Conclusions}

As already illustrated, dramatic changes have been witnessed in the Italian local government in recent decades, as in no other political-administrative level. Roles and functions of organs and actors, institutional and non-institutional, have been redesigned. Even the local policy making has undergone a profound transformation that had to take account of more political than purely administrative factors: the entire cycle of policy has assumed a new definition, highlighting instances of legitimacy more on the political supply side than on the demand one. We have previously emphasized how radical was the communicative, emotional, irrational significance and therefore, cognitive-identity of the new local policy making; all strongly characterized by a high degree of personalization and unconditional adherence to the leader: someone spoke also of bio-leadership (Esposito 2004). The most obvious fact is definitely the political overexposure of demo-elected mayor, the true "flywheel" of all processes involving the local administration, the attribution center of all levels of political responsibilities related to the management of the local authority.

The empirical evidence that has been more than twenty years of "municipal political laboratory", leads us to the conclusion that a more positive result would depend not only on institutional and administrative reforms but also on changes in the actors' culture, in their decision-making styles, in their ability to be in relationship. In conclusion, let's try to outline some, albeit brief, response. In order to be effective in his/her top actions of the local government, the mayor must be able to play the role / function of innovator / promoter of policy initiatives, acting mainly cognitively through a 
reformulation and a new interpretation of problems, maybe already old, the so-called re-framing: that is the "policy entrepreneur" (Roberts, King 1991; Giuliani 1998). On a more typically operational side, the mayor must also be able to build strategies and networks of actors, alliances at various levels needed to meet the policies in their new redefinition: in other words, the "political entrepreneur" (Capano, Giuliani 1996; Blyth 2002; Hwang, Powell 2005). In the empirical survey of the experiences of post-reform mayors, the two levels were not always conjugated. In particular, the decisionmaker exasperation / illusion has connoted the performance of some early Italian mayors, has proved to be counter on the side of the construction of collective inclusive action strategies, more effective also from the point of view of limitation of the conflict degree. The accentuation of the levels of personalization of politics locally has not brought, by itself, a greater capacity for solving collective problems: on the contrary, in cases where the mayor was unable - or unwilling - to establish a constructive dialogue and discussion with local interests outside the political machine and municipal administrative, the final result was the crack of the "honeymoon" between the mayor and the civil society of reference. In general, the leadership profile of the "first citizens" can be considered, if not an independent variable, at least an intervener one, for the ability to administer with the continued support of their community. The mayors of more technical profile - for the original deformation - underestimate the problem of the relationship with groups of interest and get overwhelmed by the "decision-maker illusion", feeling to be directly understood by the popular will. In fact, the design of the reform of 1993 - as well as the political climate, the majority-plebiscitarian one - tended to feed, at least in its initial impact, the "decision-maker illusion". The mayors, however, of a more typically political origin, should be more able to play the role of political entrepreneurs which, as noted above, is essential for the success of a policy; the ability to mediate and to be "synthesis" of several positions and points of view widens the basis of consent and it is undisputed the fact that this attitude ensures easier and organic phase of implementation of a policy.

The reported examples relating to the policy of the two Neapolitan administrations headed by Bassolino and De Magistris is a clear, albeit partial, confirmation of the above suggested. There is no doubt that Bassolino was more skillful and able to set the conditions, and the right reference networks, to establish the policy initiatives that can intercept the attention - and satisfaction - of citizenship; the consequence of this is translated in a high level of consent. De Magistris, in contrast, failed to create the necessary synergies with the relevant socio-political-institutional actors significant in the Neapolitan scenery, adopting a "decision-maker" style that is scarcely functional to the activation and consolidation of consent. It is not a coincidence that Bassolino embodies the typical example of professional politician, with a motivated and long party militancy, while the current mayor of Naples, De Magistris, is an expression of civil society, as magistrate (Public Prosecutor) with low level of party-political socialization. The hypothesis that the type of elite, connected to specific profiles of leadership, may - albeit only partially - help explain the results of the new local policy making, give new shine to the interpretation of the contemporary political processes for too long denied.

\section{References}

Allum, P. 1997. "Nuovi sindaci e vecchia politica", II Tetto, 202: 67-80.

Amato, M. 2012. De Magistris o della rivoluzione napoletana. Napoli: Fuorionda.

Baccetti, C. 1999. Poteri locali e politiche pubbliche. Torino: Utet

Barbagallo, F. 1997. Napoli fine Novecento. Politici, camorristi, imprenditori. Torino: Einaudi.

Bentivegna, S. 2014. La politica in 140 caratteri. Twitter e spazio pubblico. Milano: FrancoAngeli.

Blyth, M. 2002. Great Transformations. Economic Ideas and Institutional Change in the Twenties Century. Cambridge: Cambridge University Press.

Caciagli, M. and Di Virgilio, A., eds. 2005. Eleggere il sindaco. La nuova democrazia locale in Italia e in Europa. Torino: Utet

Calise, M. 1988. "Organizzare le politiche: arene di partito e arene amministrative a Napoli, 1975-1983", Democrazia e diritto, 27 (6): 163-187.

Calise M., ed. 1992. Come cambiano i partiti. Bologna: il Mulino.

Calise, M. 2010. II partito personale. I due corpi del leader. Roma-Bari: Laterza.

Canzano, A. 2012. Sindaci e giovani sindaci. Dinamiche di trasformazione nella politica locale. Milano: FrancoAngeli.

Capano, G. 2009a, "Tra leadership e tempo. Le dimensioni sfuggenti del cambiamento delle politiche". Rivista italiana di politiche pubbliche. 3: 5-30.

Capano, G. 2009b. "Political Change and Policy Change: Some Notes on the Role of Leadership as a Theoretical and Empirical Problem", paper presented at XXI IPSA World Congress of Political Science. Santiago, Chile, July 12-16.

Capano, G. and Giuliani, M. eds. 1996. Dizionario di politiche pubbliche. Roma: La Nuova Italia Scientifica.

Capano, G. and Howlett, M. eds. 2009. European and North American Policy Change. Drivers and Dynamics. London: Routledge.

Cappelli, O. ed. 2003. Potere e società a Napoli a cavallo del secolo. Napoli: ESI.

Castells M. 2009. Comunicazione e potere. Milano: Egea.

Catanzaro, R., Piselli, F., Ramella, F., Trigilia, C. eds. 2002. Comuni nuovi. Il cambiamento nei governi locali. Bologna: il Mulino. 
Ceccanti, S. and Vassallo, S. eds. 2004. Come chiudere la transizione. Cambiamento, apprendimento e adattamento nel sistema politico italiano. Bologna: il Mulino.

Cilento, M. 2000. Le politiche simboliche a livello locale. Il caso Bagnoli. Napoli: Liguori Editore.

Cotta, M. 1989. "Il contributo dei policy studies alla scienza politica contemporanea". in L'analisi della politica. Tradizioni di ricerca, modelli, teorie, edited by A. Panebianco, 517-541. Bologna: il Mulino.

Cotta, M. and Isernia, P. eds. 1996. II gigante dai piedi di argilla. Le ragioni della crisi della Prima Repubblica: partiti e politiche dagli anni '80 a Mani pulite. Bologna: il Mulino.

Dahl, R.A. 1961. Who governs? Democracy and power in an American city. New Haven: Yale University Press.

De Rosa, R. 2013. Cittadini digitali. L'agire politico al tempo dei social media. Rimini: Maggioli.

Donolo, C. 1977. Mutamento o transizione? Politica e società nella crisi italiana. Bologna: il Mulino.

Easton, D. 1953. The Political System. An Inquire into the State of Political Science. New York: Alfred A. Knopf.

Edelman, M. 1976. The Symbolic Uses of Politics. Urbana: University of Illinois Press.

Esposito, R. 2004. Bios. Biopolitica e filosofia. Torino: Einaudi.

Fabbrini, S. 1990. "La leadership politica nella democrazia delle comunicazioni di massa". Democrazia e Diritto, 30, (2): 161-196.

Fung, A. 2004. Empowered Participation. Reinventing Urban Democracy. Princeton: Princeton University Press.

Geremicca, A. ed. 1997. Napoli: una transizione difficile. Napoli: A. Guida.

Giuliani, M. 1998. "Sul concetto di imprenditore di policy". Rivista Italiana di Scienza Politica. 28 (2): 357-378.

Grieco, M. 1997. "Politica e comunicazione: I'Italia degli anni Novanta", in L'americanizzazione della politica in Italia. TV ed elezioni negli anni Novanta, edited by R. Savarese, 61-98. Milano: FrancoAngeli.

Hunter, F. 1953. Community power structure. A study of decision makers. Chapell Hills: The University of North Carolina Press.

Hwang, H. and Powell, W.W. 2005. "Institutions and Entrepreneurship". in Handbook of Entrepreneurship Research, edited by S.A. Alvarez, R. Agarwal, O. Sorenson, 179-210. Dordrecht: Kluwer Publishers.

Ignazi, P. 2002. Il potere dei partiti. La politica in Italia dagli anni Sessanta a oggi. Roma-Bari: Laterza.

Kavaratzis, M. 2004. "From city marketing to city branding: Towards a theoretical framework for developing city brands". Place Branding. 1, (1): 58-73.

Lakoff, G. 2008. The political mind. Why you can't understand 21 st-century politics with an $18^{\text {th }}$-century brain. New York: Viking.

Lowi, T.J. 1964. At the pleasure of the mayor. Patronage and power in New York city, 1898-1958. New York: The Free Press.

Lowi, T.J. 1972. "Four Systems of Policy, Politics and Choice". Public Administration Review, 32 (4): 298-310.

Mair, P. 1992. "La trasformazione del partito di massa in Europa", in Come cambiano i partiti, edited by M. Calise, 99-120. Bologna: il Mulino.

Marletti, C. 2010. La Repubblica dei media. L'Italia dal politichese alla politica iperreale. Bologna: il Mulino.

Marrone, T. 1996. Il sindaco. Storia di Antonio Bassolino. Milano: Rizzoli.

Mazziotti, G. 2012. Diario napoletano. Da Bassolino a De Magistris. Napoli: Tullio Pironti Ed.

Melchionda, E. 2005. Alle origini delle primarie. Democrazia e direttismo nell'America dell'età progressista. Roma: Ediesse.

Mény, Y. and Surel Y. 2001. Populismo e democrazia. Bologna: il Mulino.

Morello, M. 2007. Governare la quotidianità. Sindaci di Sicilia. Milano: FrancoAngeli.

Musi, A. 2002. La stagione dei sindaci. Napoli: A. Guida.

Pasotti, E. 2010. Political Branding in Cities. The Decline of Machine Politics in Bogotà, Naples and Chicago. New York: Cambridge University Press.

Pasquino, G. 2000. La transizione a parole. Bologna: il Mulino.

Pitkin, H.F. 1967. The concept of representation. Berkeley: University of California Press.

Roberts, N.C. and King, P.J. 1991. "Policy Entrepreneurs: Their Activity Structure and Function in the Policy Process". Journal of Public Administration Research and Theory. 1 (2): 147-175.

Schumpeter, J. A. 1954. Capitalism, Socialism and Democracy. London: George Allen \& Unwin.

Svara J.H \& Associates 1994. Facilitative Leadership in Local Government. Lessons from Successful Mayors \& Chairpersons. San Francisco: Jossey-Bass Publishers.

Tranfaglia, N. 2003. La transizione italiana: storia di un decennio. Milano: Garzanti.

Trigilia, C. 2002. "Dalla politica alle politiche: comuni e interesi locali", in Comuni nuovi. Il cambiamento nei governi locali, edited by R. Catanzaro, F. Piselli, F. Ramella, C. Trigilia, 579-604. Bologna, il Mulino.

Tuccillo, B. 2014. II sindaco con la bandana. De Magistris e la rivoluzione fallita. Napoli: CentoAutori.

Vandelli, L. 1997. Sindaci e miti. Sisifo, Tantalo e Damocle nell'amministrazione locale. Bologna: il Mulino.

Vandelli, L. 2014. II governo locale. Bologna: il Mulino.

Venturino, F. 1995. "Le conseguenze politiche del nuovo sistema elettorale comunale: un esame empirico". Quaderni dell'Osservatorio Elettorale, 34: 71-91.

Welch, S. and Bledsoe T. eds. 1988. Urban reform and its consequences. A study in representation. Chicago: The University of Chicago Press. 